УДК 624:658.5.003.1

\title{
ПРОАКТИВНА СТРАТЕГІЯ ІНФОРМАЦІЙНОЇ БЕЗПЕКИ ПІДПРИЕМСТВ БУДІВЕЛЬНОЇ ГАЛУЗІ
}

\author{
Чередниченко А.О., аспірант (ХНУМГ ім. О.М. Бекетова)
}

\begin{abstract}
В статті досліджено теоретичні аспекти стратегічного управління інформаційною безпекою підприємств будівельної галузі. Грунтуючись на тому, щзо інформачія є ключовим активом сучасних підприємств, зроблено висновок про значимість проактивних підходів при реалізаиіі стратегії забезпечення інформаційної безпеки. Шляхом використовування методу побудови дерева цілей сформовано систему иңільових орієнтирів, иілей та завдань проактивної стратегії інформаційної безпеки підприємств будівельної галузі, котра сприятиме успішній реалізаџії превентивних заходів інформаційної безпеки.

Ключові слова: стратегія, інформаційна безпека, проактивний підхід, превентивні заходи, дерево цілей, підприємства будівельної галузі.
\end{abstract}

\section{ПРОАКТИВНАЯ СТРАТЕГИЯ ИНФОРМАЦИОННОЙ БЕЗОПАСНОСТИ ПРЕДПРИЯТИЙ СТРОИТЕЛЬНОЙ ОТРАСЛИ}

\author{
Чередниченко А.О., аспирант (ХНУГХ им. А.Н. Бекетова)
}

В статье исследованы теоретические аспекты стратегического управления информационной безопасностью предприятий строительной отрасли. Учитывая, что информация является ключевьм активом современных предприятий, сделан вывод о значимости проактивных подходов при реализачии стратегии обеспечения информационной безопасности. Путем использования метода построения дерева целей сформирована система целевых ориентиров, целей и заданий проактивной стратегии информационной безопасности предприятий строительной отрасли, которая будет способствовать успешной реализации превентивных мероприятий информационной безопасности.

Ключевые слова: стратегия, информационная безопасность, проактивный подход, превентивные мероприятия, дерево целей, предприятия строительной отрасли.

\section{PROACTIVE STRATEGY OF INFORMATION SECURITY OF ENTERPRISES OF CONSTRUCTION INDUSTRY}

\section{Cherednychenko A.O., post-graduate student \\ (O.M. Beketov National University of Urban Economy in Kharkiv)}

The article investigates the theoretical aspects of strategic information security management of enterprises of construction industry. Considering that information is a key asset of modern enterprises, concluded about the importance of a proactive approach in realizing the strategy of ensuring the information security. By using, the method of constructing the tree of purposes formed a system of targets, objectives and tasks of proactive strategy of informational security of enterprises of construction industry. As a strategic guideline defined a goal - the prevention of threats to information security, and the main directions proactive work include: prevention of economic espionage; modernization of the information infrastructure; improving the system of support the management decision; formation of information culture; information support measures improve the image. Development and implementation of a proactive strategy will contribute to the successful implementation of preventive measures of information security.

Keywords: strategy, informative safety, proactive approach, preventive measures, tree of purposes, enterprises of construction industry.

Постановка проблеми та ї зв'язки 3 науковими чи практичними завданнями Сучасні підприємства будівельної галузі, котрі націлені на конкурентностійкий розвиток продовжують міняти відношення до інформаційної безпеки. Роль цієї функції поступово зростає, оскільки підприємства усвідомлюють важливість інформації як свого ключового активу. Традиційний реактивний підхід втрачає свою ефективність і підприємства прагнуть управляти даними на основі стратегічних проактивних заходів.

Аналіз останніх досліджень $і$ публікацій. Вирішенню проблем управління інформаційною безпекою присвятили праці такі вчені як 
В.В. Андріанов, С.Л. Зефіров, В.Б. Голованов, Н.А. Голдуєв, С.В. Кавун, В.В. Костров, B.I. Слєпцов, О. Лукацький, В.I. Ярочкин та інші [16], які розглядають різноманітні заходи щодо забезпечення інформаційної безпеки.

Виділення невирішених частин загальної проблеми. Враховуючи значний добуток вчених в галузі управління інформаційною безпекою, залишаються актуальними та потребують подальшого дослідження питання формування стратегії забезпечення інформаційної безпеки на підприємствах будівельної галузі, у тому числі визначення превентивних заходів попередження загроз інформаційні безпеці.

Метою статmi є розкриття цілей, завдань та заходів проактивної стратегії інформаційної безпеки будівельних підприємств.

Виклад основного

матеріалу

дослідження. Стратегія - це генеральна програма дій, що спрямована на досягнення визначених орієнтирів діяльності підприємства на підставі оцінки його потенційних можливостей i прогнозування розвитку зовнішнього середовища [7, C. 127].

В загальному випадку стратегію можна розглядати як детальний всесторонній комплексний план, призначений для того, щоб забезпечити здійснення місії й досягнення цілей підприємства найбільш ефективно. Основна задача такого плану — забезпечити нововедення і зміни на підприємстві відповідно до змін в навколишньому середовищі.

Реальна стратегія підприємства складається не тільки $з$ направлених (запланованих) дій, але і 3 реакції на непередбачені обставини. Отже, стратегію необхідно розглядати як симбіоз запланованих дій (проактивна стратегія) i адаптивної реакції на ситуацію, що виникла (реактивна стратегія) [7, С. 128].

Сьогодні термін «проактивність» широко використовується в різних науках, проте іiі узагальнююча характеристика запропонована Ньюстромом і Девісом в їх праці «Організаційна поведінка»: проактивність - це передбачення подій, ініціація змін, прагнення «тримати в своїх руках» долю організації [8, С. 343]. Саме проактивність $\epsilon$ основою конкурентоспроможності і ефективності підприємств в сучасному нестабільному світі. Виходячи 3 цього розглянемо основні направлення i цілі проактивної стратеги забезпечення інформаційної безпеки. Підхід проактивності націлений на попередження загроз інформаційної безпеки, а також на забезпечення високої якості інформації в системі прийняття управлінських рішень на підприємстві, тому вважаємо, що головною метою $є$ попередження виникнення загроз і ризиків інформаційної безпеки (рис. 1).

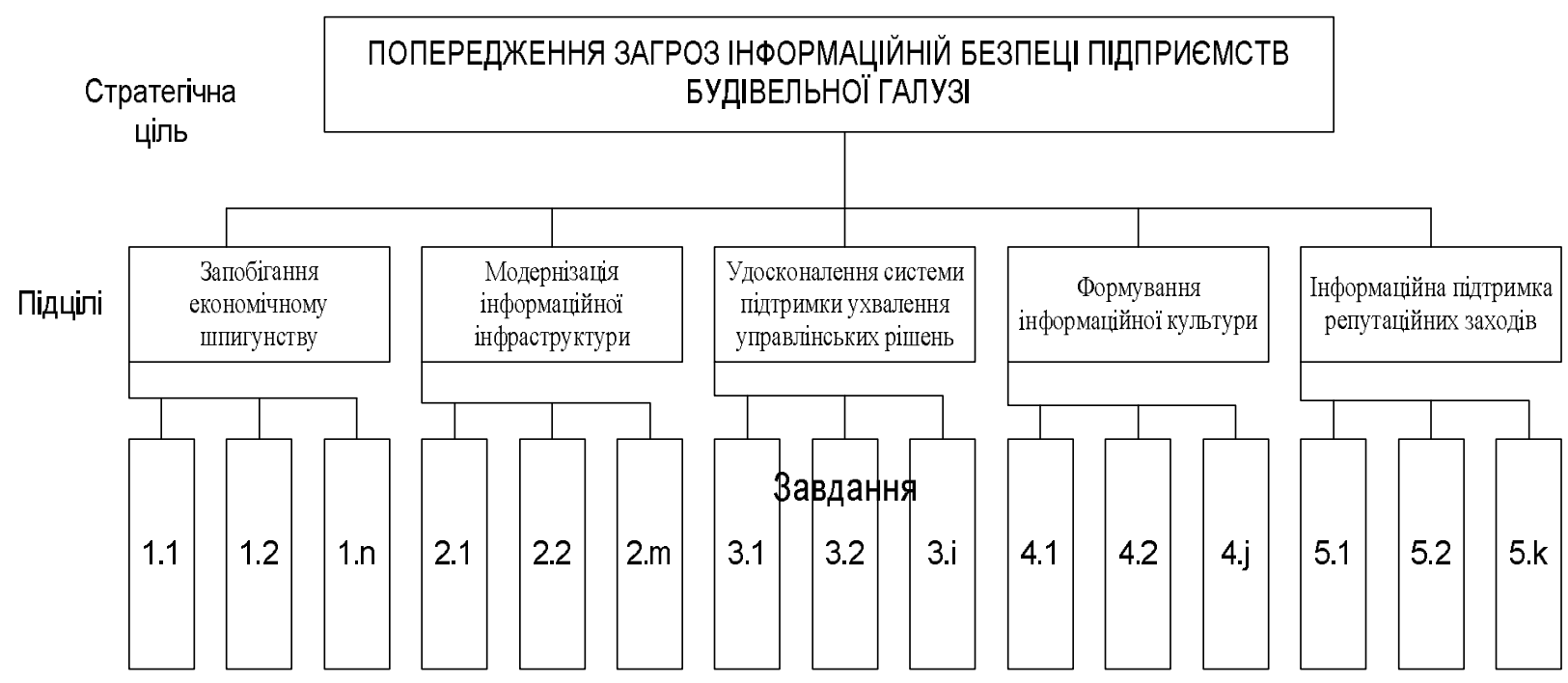

Рис. 1. Схема дерева иџілей досягнення стратегічної мети проактивної стратегї̈ інформаційної безпеки Джерело: власна розробка

В першу чергу сформуємо головні напрями проактивної роботи, а саме: запобігання економічному шпигунству; модернізація інформаційної інфраструктури; удосконалення системи підтримки ухвалення управлінських рішень; формування інформаційної культури; інформаційна підтримка репутаційних заходів.
Багато підприємств спрямовують зусилля своїх спецслужб на постійну розвідку досягнень інших підприємств, особливо їх патентів, комерційних, технологічних i виробничих таємниць. Саме тому темі економічного шпигунства, захисту інсайдерської інформації стало приділятися велика увага і ця проблематика 
набула великого значення. Методи отримання інформації охоплюють весь спектр і персонал розвідслужб, включаючи використання агентурного апарату, кадрових розвідників, можливостей резидентур, використання журналістів, практикантів, отримання інформації технічним шляхом й т.д. Але економічне шпигунство має деякі особливості, до яких відносять: аналіз відкритих джерел; отримання інформації у ході бесід, перемов, спілкування; використання сучасної електронної, інформаційної техніки i спеціальних пристроїв (комп'ютерне шпигунство; появу агентів на підприємстві. Останні являють собою найбільшу небезпеку для інтересів безпеки підприємства [9].

Економічним шпигунством у будівельній галузі займаються ті підприємства, метою яких є виготовлення власних більш дешевих копій проектів будівництва і виходу 3 ними на ринок. Для таких підприємств головним $є$ отримання технічної документації та інформації про проекти та макетів майбутніх споруд підприємствконкурентів.
Проактивні способи захисту підприємства будівельної галузі від економічного шпигунства пропонуємо визначати в залежності від методів економічного шпигунства (рис. 2).

Bce більшого значення в запобіганні виникнення загроз інформаційної безпеки належить модернізація інформаційної інфраструктури.

Для успішного створення і впровадження корпоративної інформаційної системи в будівельному підприємстві необхідно забезпечити реалізацію таких іiі основних взаємозв'язаних складових:

1) технологій, що визначають бізнеспроцеси в інформаційній системі й формалізують ï $з$ урахуванням всіх взаємозв'язків в будівельній компанії;

2) програмне забезпечення, що реалізовує необхідну функціональність інформаційної системи;

3) апаратура, що забезпечує функціонування інформаційної системи.

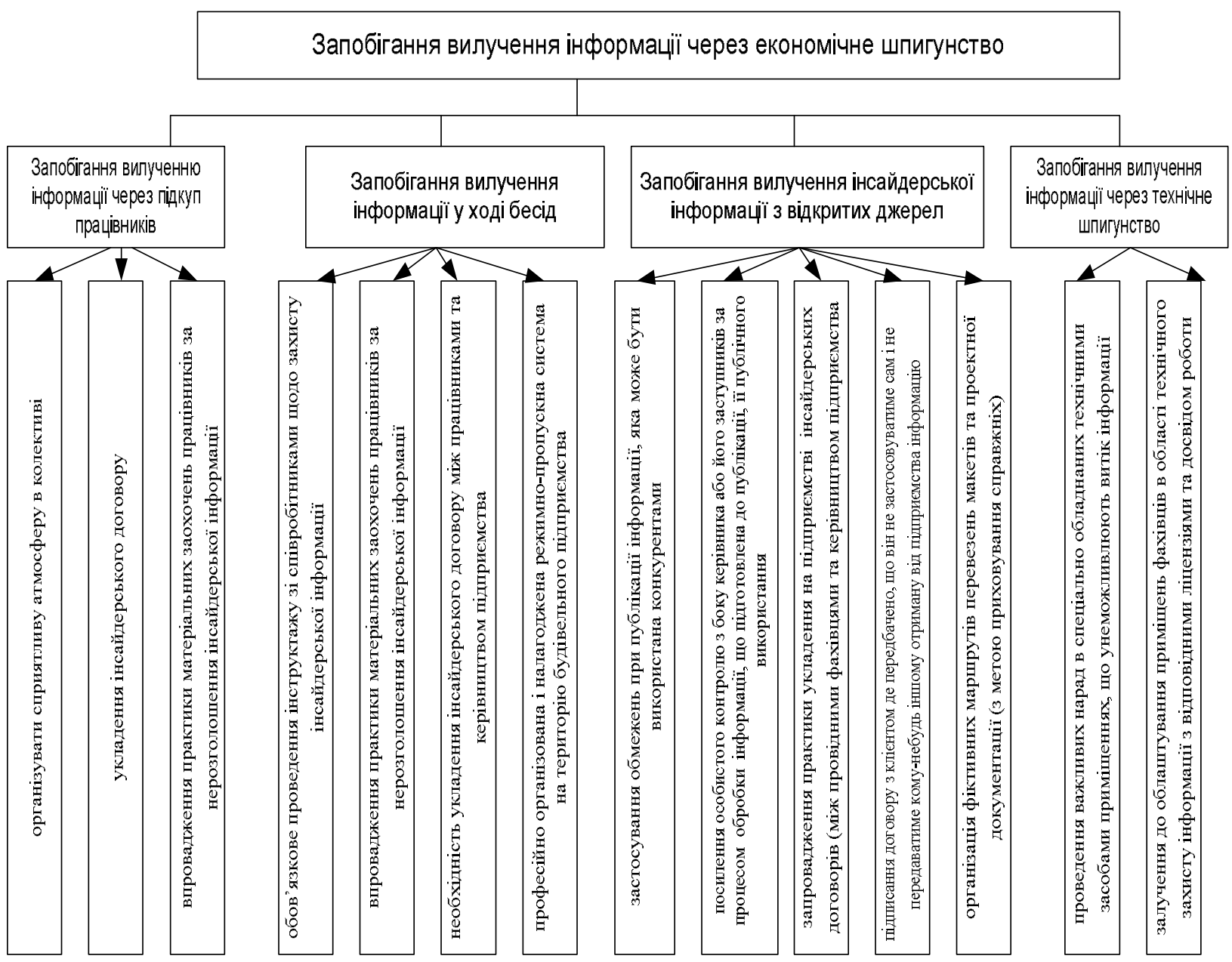

Рис. 2. Заходи із запобігання економічному шпигунству

Джерело: власна розробка 
Передові будівельні компанії в останні декілька років прагнуть використовувати все, що можуть запропонувати в галузі інформаційного сервісу. Наприклад, IP-телефонію, яка дозволяє забезпечувати віддалені майданчики телефонним зв'язком в найкоротші терміни і за економними цінами. Раніше всі будівельні підприємства намагалися вирішувати цю задачу на місцях за допомогою підключення місцевого телефону. Для цього вони залучали операторів зв'язку, які тягнули дроти до місця будівництва, що часто було неможливе через важкодоступність і віддаленості будівельних майданчиків. Так, до речі, намагаються діяти багато хто дотепер. Тим часом канал зв'язку можна організувати набагато більш простим i зручним способом, наприклад, за допомогою технологій WiMAX i 3G.

Ще одним ефективним інструментом $\epsilon$ електронна пошта. Будівельний бізнес потребує оперативного обміну інформацією між співробітниками. Наприклад, генеральному директору необхідно призначати зустрічі і наради або розсилати своїм менеджерам якісь важливі повідомлення. Для цього в передових компаніях використовується синхронізація електронної пошти, календарів i контактів на мобільних пристроях за допомогою Microsoft Exchange. При цьому вся важлива бізнес-інформація, що зберігається на сервері підлягає резервному копіюванню.

3 попереднім напрямком тісно пов'язана наступна група завдань, котра націлена на удосконалення системи підтримки ухвалення управлінських рішень. Зокрема, можна виділити наступні задачі:

1. Задачі по складанню документації, що регламентує організацію i технологію матеріальних процесів: виробництво будівельномонтажних робіт, поставки ресурсів (розчину, бетону, деталей), робота машин і механізмів, екскавація i перевезення грунту, виготовлення деталей і конструкцій й т.д. Очевидно, що в цих випадках змістовний опис задачі $\epsilon$ описом цих матеріальних процесів 3 аналізом і вказівкою, які саме процеси повинні бути регламентовані, в якій принциповій формі (графіки, розклади, моделі і т. д.) повинна бути випущена документація та яка ідея вдосконалення виробництва повинна бути використана при цьому.

2. Задачі планування діяльності організаційно-економічної системи (будівельний трест, главк, підприємство і т. д.). Для такого роду задач характерні процеси: розробка завдання (програми) 3 урахуванням директив на термін, визначення характеру планування (перспективне, поточне, оперативне), розподілу завдань по виконавцях i розрахунку показників роботи, які повинні бути досягнуті при виконанні цих планових завдань. Змістовний опис такого роду задач відображає загальні принципи планування та повинен характеризувати особливості їх реалізації в умовах даної організації, а також визначати вимоги до планової документації, автоматизацію складання якої намічається здійснювати за допомогою ЕОМ.

3. Задачі проектування об'єктів будівництва, конструкторських розробок машин i т.д. Змістовний опис таких задач може відображати творчі процеси 3 виробітки як архітектурно-планувальних рішень, так i добре формалізованих методів інженерних розрахунків, будівельних конструкцій, деталей машин, розрахунків кошторисів і т.д.

4. Задачі нормування виробничих процесів. Задачі нормування виробничих процесів, складання калькуляцій на укрупнені елементи споруд, розрахунки потреб матеріальних ресурсів й ін., в змістовному описі таких задач можуть бути виділенні процеси створення елементних норм, що розробляються на основі даних хронометражу i статистичної обробки останніх. Інший аспект цієї групи задач представляється як розрахунки калькуляції витрат праці, заробітної плати або потреби в матеріальних ресурсів на задані об'єми робіт 3 використанням елементарних або агрегованих норм.

5. Задачі контролю i регулювання виробничих процесів описуються так: інформаційні процеси отримання оперативної інформації про фактичні значення параметрів контрольованого виробництва, порівняння цих величин з розрахунковими (заданими), виявлення відхилень i вироблення i реалізацію команд управління. В будівництві змістовний опис задач оперативного контролю може включати контроль графіків-розкладів поставки ресурсів, оперативне управління ходом будівництва на основі мережних моделей, контроль за виконанням календарних планів робіт і. т.д.

6. Задачі обліку і звітності. Змістовний опис таких задач може в основному повторювати діючі інструкції, форми звітності, методи їх заповнення (i т. д.), оскільки i бухгалтерія, i статистична звітність строго регламентовані і не допускають відхилень і використовування довільних нерегламентованих форм.

7. Задачі інформаційно-довідкової служби організацій і підприємств. Йдеться, по суті справи, про створення автоматизованих довідковоінформаційних систем, заснованих на використовуванні формалізованих документів, тобто фактографічних інформаційно-довідкових систем або документальних, котрі використовують неформалізовану документацію, у тому числі науково-технічну літературу. 
Наступна група завдань пов'язана 3 формуванням інформаційної культури. Інформаційна культура - це здатність суспільства ефективно використовувати інформаційні ресурси i засоби інформаційних комунікацій; застосовувати передові досягнення в області розвитку засобів інформатизації і інформаційних технологій [10].

Інформаційна культура, будучи системою, має системоутворююче ядро, яким $\epsilon$ інформаційна діяльність. Вона $\epsilon$ продуктом різноманітних творчих здібностей людини i виявляється в наступних аспектах [11]:

$$
\text { - в конкретних навиках по }
$$

використовуванню технічних пристроїв (від телефону до персонального комп'ютера i комп'ютерних мереж);

- в вдатності використовувати в своїй діяльності комп'ютерну інформаційну технологію, базовою складовою якої $\epsilon$ численні програмні продукти;

- в умінні вилучати інформацію 3 різних джерел: як 3 періодичного друку, так і 3 електронних комунікацій, представляти іiї в зрозумілому вигляді i уміти іiі ефективно використовувати;

- у володінні основами аналітичної переробки інформації;

- в умінні працювати 3 різною інформацією;

- в знанні особливостей інформаційних потоків в своїй області діяльності.

Завдання управління інформаційною культурою полягає в:

- підвищенні кваліфікації в галузі IT-

технологій;

- дотриманні норм інформаційної етики; формуванні психологічних установок щодо ефективного використання ITтехнологій та інформації.

Важливим напрямком інформаційної безпеки вважаємо захист інформації щодо репутації підприємств будівельної галузі. 3 цією метою доцільно здійснювати моніторинг інформації про підприємство за такими напрямами [192]: моніторинг інформаційного поля бренду; моніторинг конкурентів; моніторинг клієнтського сервісу; моніторинг при розробці продукту; моніторинг антикризових комунікацій; моніторинг ефективності реклами і маркетингу; моніторинг пошукової оптимізації; моніторинг публікацій засобів масової інформації.

Перераховані види моніторингу допомагають швидко проаналізувати репутацію, привернути нову аудиторію i побудувати ефективні стратегічні і тактичні плани поведінки підприємства на ринку.

\section{Висновки даного дослідження $i$ перспективи подальших робіт у цьому} напрямку. Таким чином, на основі використовування методу побудови дерева цілей сформована система орієнтирів, цілей і завдань проактивної стратегії інформаційної безпеки підприємств будівельної галузі. В якості стратегічного орієнтира визначена мета попередження загроз інформаційній безпеці, а до головних напрямів проактивної роботи віднесені: запобігання економічному шпигунству; модернізація інформаційної інфраструктури; удосконалення системи підтримки ухвалення управлінських рішень; формування інформаційної культури; інформаційна підтримка заходів підвищення іміджу. Реалізація запропонованих заходів дозволяє створити дієву систему попередження виникнення загроз інформаційної безпеки на підприємствах будівельної галузі.

\section{СПИСОК ЛІТЕРАТУРИ}

1. Андрианов В. В. Обеспечение информационной безопасности бизнеса [Электронный ресурс] / В. В. Андрианов, С. Л. Зефиров, В. Б. Голованов, Н. А. Голдуев. - Режим доступа:

http://bezopasnik.org/article/book/andrianov_infobez biz_2011.pdf

2. Інформаційна та економічна безпека діяльності підприємства: конспект лекцій / В. І. Слепцов.- Запоріжжя: ЗНТУ, 2007. - 70 с.

3. Кавун С. В. Информационная безопасность в бизнесе / С. В. Кавун. - Харьков: Изд. ХНЭУ, 2007. - 408 с.

4. Костров А. В. Основы информационного менеджмента : учеб. пособие / А. В. Костров; 2-е изд., перераб. и доп. - М. : Финансы и статистика, 2004.- 528 с.

5. Лукацкий А. Что понимается под оценкой эффективности информационной безопасности? [Электронный ресурс]. - Режим доступа : http://www.globalcio.ru/experts/

6. Ярочкин В. И. Основы защиты информации. Служба безопасности предприятия : учеб. пособие / В. И. Ярочки, Д. Б. Халупин. - М. : ИПКИР, 1993.- 42 с.

7. Дикань В. Л. Стратегічне управління : навч. посібник / [В. Л. Дикань, В. О. Зубенко, О. В. Маковоз, І. В. Токмакова, О. В. Шраменко]. - К.: Центр учбової літератури, 2013. - 272 с.

8. Ньюстром Д. Организационное поведение : поведение человека в процессе труда / Д. Ньюстром, К. Дэвис ; пер. с англ. ; под ред. Ю. Н. Каптуревского. - СПб. : Питер, 2000. - 447с.

9. Про розвідувальні органи України : [закон України : офіц. текст : за станом на 18 квітня 2001 р., із змінами, внесеними Законом 
України від 01 січня 2014 р.] : [Електронний ресурс]. - Режим доступу : http://zakon1.rada.gov.ua/laws/show/2331-14 10. Лапина Н. А. Управление информационной культурой персонала : автореф. дис. на соискание науч. степени канд. экон. наук : спец. 08.00.05 «Экономика и управление народным хазяйством» / Н. А. Лапина. - СПб., 2003. - 24 с.
11.Пронина Л. А. Информационная культура как фактор развития информационного общества [Электронный ресурс] / Л. А. Пронина // Аналітика культурологии. - 2008. - №10. - Режим доступа

http://cyberleninka.ru/article/n/informatsionnayakultura-kak-faktor-razvitiya- informatsi onnogoobschestva

Рецензент д.е.н., професор УкрДАЗТ Кірдіна О.Г. Експерт редакційної колегії к.е.н., доцент УкрДАЗТ Токмакова І.В.

\title{
УДК 363.03.019 \\ ОЦІНЮВАННЯ РИЗИКІВ МАШИНОБУДІВНИХ ПІДПРИЕМСТВ: АНАЛІТИКО-ІНСТРУМЕНТАЛЬНА ТЕХНОЛОГІЯ
}

\author{
Черепня Г.М., здобувач (УІІА)
}

У статті удосконалено аналітико-інструментальну технологію оцінювання ризиків підприємства, задача якої заключається в чисельному вимірі впливу факторів ризику на ефективність функиіонування машинобудівних підприсмств. Розрахувавши інтегральний показник оцінки складових ризику машинобудівних підприємств за 7 років було визначено, щчо найменш плідними для діяльності більшості з них були 2008, 2010-2012 роки. В дані періоди інтегральний показник для більшості підприємств набував низького значення, щзо може бути спричинено впливом на їх функиіонування зовнішніх факторів ризику, таких як нестабільність економічного стану держави, недосконалість законодавства в галузі, зростання цін на сировину, матеріали, напівфабрикати, паливо, устаткування, обладнання та інші складові виробничого прочесу. Ця ситуачія негативно позначилася на діяльності машинобудівних підприємств, оскільки спричинила зменшення випуску продукиї або виготовлення $i$ заміну їі на аналогічну, але більш низької якості.

Ключові слова: оцінка, методика, ризик, рівень, аналітико-інструментальна технологія, управлінське рішення.

\section{ОЦЕНКА РИСКОВ МАШИНОСТРОИТЕЛЬНЫХ ПРЕДПРИЯТИЙ: АНАЛИТИКО-ИНСТРУМЕНТАЛЬНАЯ ТЕХНОЛОГИЯ}

\author{
Черепня Г.М., соискатель (УИПА)
}

В статье усовершенствовано аналитико-инструментальную технологию оценки рисков предприятия, задача которой заключается в численном измерении влияния факторов риска на эффективность функционирования машиностроительных предприятий. Рассчитав интегральный показатель составляющих риска машиностроительных предприятий за 7 лет было определено, что наименее плодотворными для деятельности большинства из них были в 2008, 2010-2012 годы. В данные периоды интегральный показатель для большинства предприятий приобретал низкого значения, может быть вызвано влиянием на их функционирование внешних факторов риска, таких как нестабильность экономического положения государства, несовершенство законодательства в области, рост иен на сырье, материаль, полуфабрикаты, топливо, оборудование, оборудование и другие составляющие производственного процесса. Эта ситуация негативно сказалась на деятельности машиностроительных предприятий, поскольку причиной уменьшения выпуска продукции или изготовления и замену ее на аналогичную, но более низкого качества.

Ключевые слова: оценка, методика, риск, уровень, аналитико-инструментальная технология, управленческое решение. 